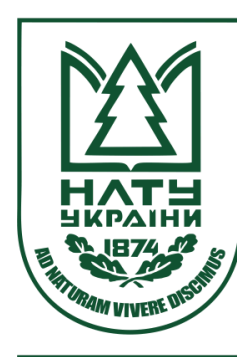

Науковий вісник НЛТУ України Scientific Bulletin of UNFU https://nv.nltu.edu.ua https://doi.org/10.36930/40290802

$@ \bowtie$ Correspondence author

Article received 19.09.2019 p.

Article accepted 31.10.2019 p.

V. V. Lavrov

удК 630*[228+272+46]

vitaliy.lavrov@gmail.com

В. В. Лавров, О. І. Слободенюк, Л. А. Савчук

Білочерківський національний аграрний університет, м. Біла Церква, Украӥна

\title{
СТАН ЗЕЛЕНИХ НАСАДЖЕНЬ МІСТА УМАНЬ
}

Досліджено вплив діяльності людини на рекреаційно-оздоровчі, захисні і природоохоронні деревостани Умані. 3'ясовано ступінь, діагностичні і просторові особливості їх порушення залежно від їх функціонального призначення, лісівничо-таксаційної характеристики, розміщення у ландшафті, відносно об'єктів комунікації та атрактивних центрів скупчення і відпочинку людей. Встановлено, що в районах найпривабливіших об'єктів дендропарку "Софіївка" дерева механічно пошкоджені, витоптується травостій і грунт, що на крутих схилах призводить до площинної і вертикальної ерозії грунту. Більше деградовані грунтозахисні та водоохоронні насадження міста у захисних смугах річок. Поблизу кладовища з могилою духовного наставника хасидів насадження дуба звичайного інтенсивно засмічені, витоптані, дерева мають механічні рани, пошкоджені вогнем. Біля заплави річки Уманки деревостани починають всихати. Це може активізувати розвинену у минулому на схилах систему ярів. У передмісті Мішанка захисні насадження середньо та інтенсивно пошкоджені лише біля річки Олександрівки, що спричинило активізацію розмивів грунту. Необхідне удосконалення організації зон відпочинку і регулювання їх відвідування з урахуванням ландшафтно-екологічних, урбоекологічних та природоохоронних норм. Актуальним $\epsilon$ збереження пріоритетних захисних функцій досліджуваних насаджень.

Ключові слова: захисні насадження; рекреаційно-оздоровчі насадження; природоохоронні насадження; рекреаційна дигресія; ерозія грунту; удосконалення організації і регулювання зон відпочинку.

Вступ. У структурі урбанізованих ландшафтів зелені насадження, особливо захисного і рекреаційно-оздоровчого призначення, відіграють значну роль буферних, регулятивних і стабілізаційних елементів, знижують поширення та негативний вплив антропогенних чинників. Вони, а також природоохоронні лісові об'єкти, мають важливе рекреаційне, декоративно-естетичне, оздоровче, соціально-історичне і загалом культурне значення для населення, оптимізують умови життя людини, середовищ існування міської біоти. Проте за недостатнього регулювання розвитку населених пунктів, транспортних мереж, загалом - природокористування лісові насадження зелених зон зазнають негативного впливу й погіршують свою структуру, знижують продуктивність та екологічну роль. Серед комплексу відомих урбаністичних чинників значної уваги заслуговує рекреаційний влив, який істотно зростає в місцях значної концентрації людей - у центрі міста, в районах торгових, освітніх, культурних закладів, установ, у парках, біля водойм, інших місцях розваг і відпочинку (Kucheriavyi, 1999; Lavrov et al., 2015, 2017; Williams et al., 2015; Maltseva et al., 2017; Rat et al., 2017). Тому формування природної підсистеми міста (системи озеленених територій) потрібно здійснювати на сучасних засадах містобудування, урбоекології, конструювання стабільного й сприятливого для життя простору урбоекосистем 3 урахуванням законодавчих принципів регулювання впливу екологічних чинників (Kucheriavyi, 1999). Зокрема, у водоохоронних зонах водних об'єктів законодавством установлено спеціальний режим, який має запобігти їх забрудненню, засміченню і вичерпанню, знищенню навколоводних рослин і тварин, а також зменшенню коливань стоку (Resolution of the Cabinet of Ministers of Ukraine № 486, 1996). У межах водоохоронних зон виділено землі прибережних захисних смуг та смуги відведення з особливим режимом їх використання відповідно до статей 87-91 Водного кодексу України.

Сприятливі природні умови і багаті ресурси Правобережного Лісостепу України, а також історичні події забезпечили інтенсивний соціально-економічний та культурний розвиток регіону. Проте, окрім позитивних здобутків, це призводить до надмірного впливу на навколишнє природне середовище. Характерною областю у цьому аспекті є Черкащина. Серед міст області Умань широко відома завдяки дендрологічному парку НАН України "Софіївка" (дендропарк), а також могили єврейського духовного наставника хасидів, рабина Нахмана. Це мотивує значний наплив відвідувачів у місто, що спричиняє істотне навантаження на біотичні складові урбоекосистеми, зокрема на захисні, рекреаційно-оздоровчі та природоохоронні насадження, пригнічення їхнього розвитку, а подекуди їх руйнацію, зниження

Інформація про авторів:

Лавров Віталій Васильович, д-р с.-г. наук, професор, завідувач кафедри загальної екології та екотрофології. Email: vitaliy.lavrov@gmail.com; https://orcid.org/0000-0003-1990-4563

Слободенюк Оксана Іванівна, канд. біол. наук, доцент, кафедра загальної екології та екотрофологіï. Email: oksana_sl@ukr.net; https://orcid.org/0000-0002-6966-9277

Савчук Людмила Анатоліївна, здобувач, кафедра загальної екології та екотрофології. Email: Iyudatec@meta.ua

Цитування за ДСтУ: Лавров В. В., Слободенюк О. І., Савчук Л. А. Стан зелених насаджень міста Умань. Науковий вісник НлТУ України. 2019, т. 29, № 8. С. 25-30.

Citation APA: Lavrov, V. V., Slobodeniuk, O. I., \& Savchuk L. A. (2019). The state of green plantations in Uman. Scientific Bulletin of UNFU, 29(8), 25-30. https://doi.org/10.36930/40290802 
екологічної ролі (Marno-Kutsa, 2014; Lavrov et al., 2015, 2017). Проте досі більшість дослідників увагу зосереджують переважно на питаннях інтродукції та акліматизації певних видів, розвитку дендропарку "Софіївка", естетичній та біометричній оцінці його деревостанів, рекреаційного впливу на його розарій, збагачення різноманіття видів у регіоні тощо. Дослідження структури, стану та виконання екологічних функцій насадженнями зеленої зони лише розпочинаються. Наразі О. Ю. МарноКуца (Marno-Kutsa, 2014) здійснила класифікацію паркових насаджень історичної частини Умані за функціональними і територіальними ознаками, їх ландшафтноархітектурний і таксономічний аналіз. Їх видовий склад і декоративність охарактеризував О. В. Гербут (Herbut, 2008). Використання і санітарний стан хвойних у зелених насадженнях міста дослідив В. М. Грабовий (Hrabovyi, 2013). Розпочато оцінку ураження парків Viscum album L. (Shlapak et al., 2013). Водночас, досі недостатньо оцінено вплив діяльності людини на рекреаційно-оздоровчі, захисні і природоохоронні деревостани міста на ландшафтно-екологічному рівні, хоча рекогносцирувальне обстеження території Умані і дослідження нами дендропарку "Софіївка" та урочища "Білогрудівська дача" свідчать, що вони є істотними (Lavrov et al., 2015, 2017). Для збереження й оптимізації структури зеленої зони міста, підвищення ії̈ екологічної ефективності необхідно врахувати зазначені проблеми, а також наявний досвід щодо створення й утримання зелених насаджень у містах Європи та його використання в Україні (Laptiev, 1998; Kucheriavyi, 1999; Ricotta et al., 2009; Williams et al., 2015; Simmons et al., 2016; Rat et al., 2017). Це сприятиме ефективнішій реалізації "Програми благоустрою міста Умань на 2016-2020 роки".

Мета роботи - з'ясувати ступінь і просторові особливості рекреаційного впливу на захисні, рекреаційнооздоровчі та природоохоронні насадження міста Умані та оцінити загрози зниження їх екологічної ролі. Об'єктом дослідження є рекреаційний вплив на захисні, рекреаційно-оздоровчі та природоохоронні насадження, а предметом - екологічні чинники, джерела їх походження, показники рекреаційної дигресії насаджень, просторові особливості їх пошкодження.

Матеріал та методика дослідження. На території міста досліджували об'єкт природоохоронного, наукового, історико-культурного призначення - дендропарк "Софіївка", а також рекреаційно-оздоровчі лісопаркові насадження різної лісівничо-таксаційної характеристики, що зростають у водоохоронних зонах річок міста і виконують грунтозахисні та водоохоронні функції (табл. 1).

Табл. 1. Лісівничо-таксаційна характеристика і санітарний стан досліджуваних захисних та рекреаційно-оздоровчих насаджень міста Умань

\begin{tabular}{|c|c|c|c|c|c|c|c|c|}
\hline ПП & $\mathrm{C}$ & Координата GPS & $\begin{array}{c}\text { Структура і породний склад } \\
\text { деревостану }\end{array}$ & $D, \mathrm{~cm}$ & $H$, м & $N$, шт./га & 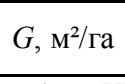 & Ic \\
\hline \multicolumn{9}{|c|}{ Грунтозахисне та рекреаційно-оздоровче насадження біля кладовища з могилою наставника хасидів рабина Нахмана } \\
\hline \multirow{2}{*}{1} & \multirow{2}{*}{3} & $48^{\circ} 45^{\prime} 2.84^{\prime \prime} \mathrm{N}(48.75079)$ & \multicolumn{6}{|c|}{ I ярус; $10 Д 3 ; 3 Д Н ~-0,75 ; \alpha-3^{\circ}$} \\
\hline & & $30^{\circ} 14^{\prime} 53.28^{\prime \prime} \mathrm{E}(30.248132)$ & Дуб звичайний & 27,8 & 21,8 & 248 & 33,9 & 3,51 \\
\hline \multirow{2}{*}{1} & \multirow{2}{*}{2} & $48^{\circ} 44^{\prime} 58.48^{\prime \prime} \mathrm{N}(48.749579)$ & \multicolumn{6}{|c|}{ I ярус; $10 Д 3 ; 3 Д Н ~-0,86 ; \alpha-6^{\circ}$} \\
\hline & & $30^{\circ} 14^{\prime} 57.4^{\prime \prime} \mathrm{E}(30.249277)$ & Дуб звичайний & 29,1 & 22,4 & 288 & 36,1 & 2,63 \\
\hline \\
\hline \multirow{2}{*}{\multicolumn{2}{|c|}{2}} & \multicolumn{7}{|c|}{\begin{tabular}{c}
\multicolumn{2}{c}{ Грунтозахисне насадження на терасах схилу до ставу Звірки } \\
$48^{\circ} 44^{\prime} 27.47^{\prime \prime} \mathrm{N}(48.748890)$
\end{tabular}} \\
\hline & & $30^{\circ} 15^{\prime} 51.93^{\prime \prime} \mathrm{E}(30.257201)$ & Дуб звичайний & 23,2 & 15,9 & 314 & 36,6 & 2,64 \\
\hline \multicolumn{9}{|c|}{ Грунтозахисне насадження на схилі до ставу біля кар'єру "Карпівка", передмістя Мішанка } \\
\hline \multirow{9}{*}{3} & \multirow{9}{*}{1} & \multirow{9}{*}{$\begin{array}{l}48^{\circ} 46^{\prime} 29.8^{\prime \prime} \mathrm{N}(48.774945) \\
30^{\circ} 10^{\prime} 11.53^{\prime \prime} \mathrm{E}(30.169869)\end{array}$} & \multicolumn{6}{|c|}{ I ярус; 8Акб2Лпд+Клг; ЗДН - 0,96; $\alpha-22^{\circ}$} \\
\hline & & & Акація біла & 28,5 & 23,9 & 186 & 29,5 & 2,63 \\
\hline & & & Липа дрібнолиста & 29,6 & 26,2 & 41 & 6,5 & 2,61 \\
\hline & & & Разом I ярус & 28,7 & 24,4 & 157 & 24,9 & 2,62 \\
\hline & & & \multicolumn{6}{|c|}{ II ярус; 6Акб4Лпд } \\
\hline & & & Акація біла & 18,7 & 17,5 & 112 & 6,9 & 2,34 \\
\hline & & & Липа дрібнолиста & 22,4 & 15,4 & 88 & 5,4 & 2,71 \\
\hline & & & Разом II ярус & 20,2 & 16,7 & 102 & 6,3 & 2,49 \\
\hline & & & Разом на ПП & 26,9 & 22,9 & 145 & 21,0 & 2,65 \\
\hline \multirow{10}{*}{3} & \multirow{10}{*}{3} & \multirow{10}{*}{$\begin{array}{l}48^{\circ} 46^{\prime} 20.56^{\prime \prime} \mathrm{N}(48.772378) \\
30^{\circ} 10^{\prime} 16.16^{\prime \prime} \mathrm{E}(30.171156)\end{array}$} & \multicolumn{6}{|c|}{ I ярус; 7Акб2Лпд1Клг; ЗДН - 0,84; $\alpha-8^{\circ}$} \\
\hline & & & Акація біла & 29,2 & 22,4 & 196 & 29,1 & 3,28 \\
\hline & & & Липа дрібнолиста & 28,1 & 21,5 & 61 & 9,1 & 3,36 \\
\hline & & & Клен гостролистий & 27,3 & 21,6 & 40 & 5,9 & 1,62 \\
\hline & & & Разом I ярус & 28,7 & 22,1 & 153 & 22,8 & 3,13 \\
\hline & & & \multicolumn{6}{|c|}{ II ярус; 7АбЗБп } \\
\hline & & & Акація біла & 26,3 & 19,1 & 88 & 9,5 & 2,64 \\
\hline & & & Береза повисла & 22,4 & 18,8 & 33 & 3,5 & 3,23 \\
\hline & & & Разом II ярус & 25,1 & 19,0 & 72 & 7,7 & 2,82 \\
\hline & & & Разом на ПП & 27,8 & 21,3 & 133 & 19,0 & 3,05 \\
\hline \multicolumn{9}{|c|}{ Берегозахисна лісосмуга біля ставу, створеному на річці Олександрівка } \\
\hline \multirow{4}{*}{\multicolumn{2}{|c|}{4}} & \multirow{4}{*}{$\begin{array}{c}48^{\circ} 46^{\prime} 16.05^{\prime \prime} \mathrm{N}(48.771125) \\
30^{\circ} 10^{\prime} 25.2^{\prime \prime} \mathrm{E}(30.173668)\end{array}$} & \multicolumn{6}{|c|}{ I ярус; 5Дз5Яз; ЗДН $-0,86 ; \alpha-3^{\circ}$} \\
\hline & & & Дуб звичайний & 31,6 & 22,6 & 317 & 48,4 & 3,31 \\
\hline & & & Ясен звичайний & 29,8 & 25,1 & 325 & 49,6 & 2,62 \\
\hline & & & Разом на ПП & 30,7 & 23,8 & 321 & 49,0 & 2,98 \\
\hline
\end{tabular}

Примітка: ПП - пробна площа; $\mathrm{C}$ - секції ПП за рівнями рекреаційного навантаження на лісові екосистеми: С1 - помірний, С2 - середній та С3 - інтенсивний. Характеристика деревостану: ЗДН - зімкнутість деревного намету, $D$ - середній діаметр; $H$ - середня висота; $N$ - густота; $G$ - сума площ перетинів стовбурів; Ic - індекс стану. Деревні породи: Дз - дуб звичайний (Quercus robur L.), Акб - акація біла (Robinia pseudacacia L.), Лпд - липа дрібнолиста (Tilia cordata Mill.), Клг - клен гостролистий (Acer platanoides L.), БП - береза повисла (Betula pendula Roth.); Яз - ясен звичайний (Fraxinus excelsior L.). $\alpha$ - крутизна схилу. 
У прибережній захисній смузі річки Уманки, в районі вул. Визволителів: а) лісові культури Quercus robur L. (10Дз; площа 6,89 га) біля кладовища 3 могилою духовного наставника хасидів, рабина Нахмана - насадження рекреаційного і грунтозахисного призначення, створене на правобережному схилі (3-6) до долини річки, перетвореній у цій частині у став Звірки, над яром довжиною $(L)-188$ м, площею $(S)-0,58$ га (ПП1); б) грунтозахисні лісові культури складом 10Дз на терасах, створених на схилі крутизною 9-16 до ставу Звірки (ПП2). У прибережній захисній смузі річки Олександрівки, притоки р. Уманки (північно-західна околиця передмістя Мішанка біля дороги на с. Городецьке): а) лісові культури (7Аб2Лпд1Клг; 4,2 га), створені на схилі 8-22 до ставу, біля кар'єру площею 4,1 га з видобутку граніту (ПП3); б) берегозахисну лісосмугу лінійної конфігурації уздовж надзаплавної бровки, з протилежного боку ставу нахилом $3^{\circ}$ (ПП4).

Дослідження здійснювали на методологічних засадах лісознавства, урбоекології, ландшафтної екології та ерозієзнавства (Vorobev, 1967; Anuchin, 1982; "Sanitary rules in the forests of Ukraine", 1995; Laptiev, 1998; Kucheriavyi, 1999; Pylypenko et al., 2004). Пробні площі (ПП) вибирали у репрезентативних ділянках зелених насаджень маршрутним методом за принципами порівняльної екології, градієнтного аналізу. За потреби диференціації рівнів рекреаційного навантаження на лісові екосистеми у межах ПП виділяли їх секції (C) - iнтенсивного (C3), середнього (C2) та помірного (C1) впливу відповідно до встановленої лісовпорядкуванням шкали визначення 1-6 стадій рекреаційної дигресії лісових насаджень, що грунтується на оцінці стану деревостану, підросту, підліску, живого надгрунтового покриву i поверхні грунту 3 урахуванням методики УкрНДІЛГА (Voron et al., 2011). Контролем вважали ідентичні за лісівничо-таксаційними показниками, більш віддалені від джерела негативних чинників і кращі за станом ділянки лісу. Місцезнаходження і розміри підібраних об'єктів визначали за картами Google Earth, програмою "ХКАРТА" і навігаційною системою позиціонування GPS.

Характеризували рельєф і рослинний покрив теритоpiї, а також просторовий розподіл проявів антропогенних порушень екосистем. Яружне порушення грунтового покриву території - як наслідок зниження грунтозахисної ролі насаджень - оцінювали за: кількістю ярів, їх довжиною, шириною, глибиною, площею, ступенем розчленування ярами території. Лінійні розміри і площу ланок гідрографічної мережі, доріг, стежок, ділянок деградації живого надгрунтового покриву (ЖНП) і грунту визначали рулеткою, а вугломірні - висотоміром "ИУ1 M". Ступінь рекреаційного впливу на лісові екосистеми визначали візуально та інструментально за розмірами і частотою трапляння ділянок засмічення, витоптування, випалювання ЖНП, лісової підстилки і поверхні грунту, а також ран механічного пошкодження дерев (Voron et al., 2011; Poliakov \& Plugatar, 2009). Стан лісових екосистем оцінювали за лісівничо-таксаційними, геоботанічними показниками 3 урахуванням порушення ЖНП, лісової підстилки і грунтового покриву. Враховували привабливість та доступність зелених насаджень для рекреантів за визначеними лісовпорядкуванням класами естетичної оцінки і пішохідної доступності ділянки 3 урахуванням методики (Voron et al., 2011).
Результати дослідження та їх обговорення. Місто обласного значення Умань, що на Черкащині, має площу 41 км² $^{2}$ Воно розташоване на Придніпровській височині, де зливаються річки Кам'янка і Уманка, що належать до басейну Південного Бугу. Територія відноситься до Христинівсько-Звенигородського геоботанічного району Умансько-Канівського геоботанічного округу. Через місто пролягає автошлях Черкаси - Умань Гайсин - Брацлав (317 км), поруч із містом проходить автошлях M05 (Київ - Одеса), що в Україні збігається 3 міжнародним автошляхом Е95 (Санкт-Петербург - Одеса) та Е50 (Ужгород - Довжанський). Кількість населення у місті на 01.01.2019 становило 83,2 тис. осіб, проте воно зростає. Тому структурно-функціональна організація зеленої зони міста, іiі рекреаційного комплексу потребує розвитку, збереження та удосконалення. За даними В. М. Грабового (Hrabovyi, 2013), структура зелених насаджень Умані є такою: ліси державного лісового фонду України (52 \%), дендропарк "Софіївка" (20\%), колективні сади (16\%), водоохоронні, меліоративні та інші захисні насадження (12\%). Усі ці деревостани займають 19,7 \% площі міста (або 941,4 га). За О. В. Гербут (Herbut, 2008), наразі площа озелененої території загального користування у місті становить 22,6 га (2,3 м² на 1 мешканця). Автор рекомендує втричі збільшити площу зелених насаджень та розширити асортимент деревних і кущових порід.

Рекогносцирувальне обстеження показало, що усі категорії насаджень, як структурні компоненти зеленої зони у межах міста, тією чи іншою мірою об'єднані функціональними і просторовими зв'язками через гідрографічну мережу, іiі грунтово-гідрологічний режим та систему захисних деревостанів лінійної конфігурації вздовж автомобільних доріг, вулиць, будинків, а також внутрішньоквартальних насаджень, утворюючи місцями цілісну, а у щільно забудованих, заасфальтованих ділянках розірвану систему деревостанів. Як відомо, окрім зазначеного пріоритетного призначення вони виконують також інші корисні функції. Виявлено, що міські зелені насадження зазнають негативного антропогенного впливу, особливо рекреаційної дигресії у центральному і промисловому густонаселених та соціально-економічно розвинених районах - за неоптимального облаштування об'єктно-функціональної структури і неналежного регулювання потоків людей. Саме у центрах концентрації людей, зв'язаних 3 їх проживанням, роботою, навчанням, побутом, відпочинком та іншими діями, що мотивують збільшення частоти і кількості напливу відвідувачів, рекреаційно-оздоровчі та захисні насадження потребують особливої уваги щодо збереження та підвищення їх екологічної ролі.

Серед об'єктів природоохоронного, наукового, історико-культурного призначення чи не найбільш атрактивним центром постійної рекреації та пізнання природи є дендропарк "Софіївка". Завдяки розвиненій і обладнаній інфраструктурі, доволі добре організованому регулюванню відвідувань та кваліфікованому догляду його екосистеми зберігаються загалом на належному рівні. Проте в районах найпривабливіших об'єктів дендропарку виявлено низку антропогенних загроз порушення його стабільності: витоптування рослинного i грунтового покриву (6,3 \% стежок - позаплановою мережею шляхів), площинну і вертикальну ерозію грунту, особливо на крутих (понад 20) схилах, забруднення 
гідрологічної мережі скидами і продуктами ерозії, механічне і пірологічне пошкодження дерев, інвазію рудерантів. Походження, просторове поширення негативних чинників залежно від рельєфу, елементів інфраструктури, рекреаційної привабливості структурних компонентів дендропарку, механізми і ступінь впливу на них, а також умови, що підсилюють негативні наслідки, показано у праці (Lavrov et al., 2015).

Значної уваги заслуговують зелені насадження, що зростають у санітарно-захисних та охоронних зонах. Мальовничі елементи ландшафту міста, парки, береги водойм приваблюють рекреантів, що подекуди спричиняє дигресію насаджень, зниження їх захисних властивостей, від чого можуть постраждати інші об'єкти суміжних територій. Прикладом урбаністичного порушення водорегулювальної та грунтозахисної функцій рослинного покриву, що призвело до істотної ерозії у минулому грунтів, є сучасний стан передбровкого схилу до правого берега ставу Звірки, створеного на p. Уманці. Так, на схиловій ділянці площею 13,6 га, протяжністю 1,2 км від вул. Степана Бандери (автошляху Київ - Одеса) до вул. Визволителів через 100-150 м сформувалося чотири яри, які мають такі довжину і площу: 1) 188 м, 0,58 га; 2) 77 м, 0,22 га; 3) 46 м, 0,08 га; 4) 55 м, 0,05 га. Вони займають 6,8 \% зазначеної території, ступінь іiі розчленування ярами становить 26,9 м/га. Найбільший із ярів (довжина 188 м) наразі неактивний, заріс травостоєм і має таку характеристику. У зоні його вершини глибина від бровки становить 1,7 м, ширина - 1,5 м, ухил дна - $9^{\circ}$. На відстані 30 м від вершини, нижче по яру його глибина зростає до 5,7 м; крутизна правого схилу (рухаючись від конуса виносу до вершини) - $32^{\circ}$, а довжина $-8,4$ м; лівого схилу $-29^{\circ}$, довжина -17 м; ширина яру (від бровки до бровки) - 22 м, ширина дна - 1,2 м. На лівому схилі через кожні 6-7 м є 10 зарослих травостоєм відвершків, що мають глибину до 0,9 м, середню ширину 0,7 м. На правому схилі відвершків менше (4), вони утворились через 32-35 м, проте вони значно глибші (до 3,7 м), довжиною до 34 м, теж заросли травою. На відстані 95 м від вершини яру його глибина сягає 8,2 м, ухил дна $-7^{\circ}$, а його ширина -7 м. Крутизна правого схилу $38^{\circ}$, довжина - $16 \mathrm{~m}$, а лівого відповідно - $24^{\circ}$ та 74 м. На віддалі 120 м: глибина яру зменшується до 5,4 м, ухил дна вирівнюється до $4^{\circ}$, його ширина -8 м, крутизна правого схилу - $40^{\circ}$, довжина - 78 м (доходить до насадження дуба), ухил лівого схилу - 23, довжина - 60 м. Нижче яр має різкий (на 1,2 м) спад глибини дна, його ухил на ділянці завдовжки 20 м збільшується до $17^{\circ}$, що свідчить про інтенсивну ерозію грунту в минулому. Тут утворився вузький (дно завширшки до 1 м) і глибокий (до 3,2 м) яр в яру. Ближче до долини річки дно яру завширшки 3,2 м виположене до $3^{\circ}$ ухилу, тягнеться ще 48 м до конуса виносу продуктів ерозії.

Вірогідно, для зупинення ерозії грунту на ділянці від вул. Визволителів до долини річки, що має ухил 3-6, було створено низку грунтозахисних насаджень загальною площею 22,1 га. Серед них уваги заслуговує деревостан $Q$. robur площею 6,89 га, складом 10Дз, віком 57 років, що охоплює майже весь описаний вище найбільший яр і зупинив його розвиток (ПП1; розміщення дерев у культурі $4 \times 0,7$ м) (див. табл. 1). Це насадження наразі не має жодного спеціального елемента інфраструктури відпочинку (алей, лавок, тощо). Тому воно зазнає істотного рекреаційного навантаження внаслідок сусідства 3 кладовищем, де похований духовний наставник хасидів рабин Нахман. Щорічно у вересні, на єврейський Новий рік (Рош Ха-Шана) хасиди багатьох країн світу приїздять на його могилу, іноді понад 20 тис. осіб (2014 р.). Наслідком їх перебування $€$ значна дигресія насадження. Біля кладовища та у смузі 0-30 м від вул. Визволителів 9\% території засмічено побутовим сміттям, лісова підстилка сильно витоптана ділянками сумарною площею 36,7 м²/га (ПП1-С3). На 65 \% площі порушений ЖНП, у ньому переважають рудеральні види, загальне проективне покриття (ЗПП) яких у зріджених місцях деревостану $є$ суцільним. 32,9 \% дерев до 2,12 м висоти стовбура мають механічні рани $\left(21,4^{ \pm 1,53} \mathrm{~cm}^{2}\right)$ сумарною прощею $0,50 \mathrm{~m}^{2} /$ га, $14,6 \%$ дерев пошкоджені низовою пожежею (висота нагару $0,25-0,87 \mathrm{~m}$; його середня площа $\left.0,53^{ \pm 0,06} \mathrm{M}\right)$. Деревостан починає всихати $(\mathrm{Ic}=3,51)$. Підріст і підлісок відсутні, хоча зімкнутість деревного намету (ЗДН) становить 0,75. Всередині парку (30-60 м від вул. Визволителів) прояви дигресії не такі значні: зімкнутість крон дерев більша - 0,86, втричі менше стежок, ЖНП витоптаний лише на $3 \%$ площі, а лісова підстилка - на $4 \%$, засмічено лише $1 \%$ території, механічно пошкоджені поодинокі дерева, слідів їх пошкодження вогнем немає (табл. 1, 2).

Табл. 2. Характеристика механічного пошкодження дерев захисних та рекреаційно-оздоровчих насаджень міста Умань

\begin{tabular}{|c|c|c|c|c|c|}
\hline \multirow{2}{*}{$\begin{array}{c}\text { ПП-С, } \\
\text { площа, } \\
\text { га }\end{array}$} & \multirow{2}{*}{$\begin{array}{c}\text { Характеристи- } \\
\text { ка I ярусу дере- } \\
\text { востану }\end{array}$} & \multirow{2}{*}{$Q, \%$} & \multicolumn{2}{|c|}{ Площа ран } & \multirow{2}{*}{$\frac{\mathrm{H}, \mathrm{M}}{\underline{\min -\max }}$} \\
\hline & & & $S_{i}, \mathrm{~cm}^{2}$ & $\begin{array}{l}S_{12 a}, \\
\mathrm{M}^{2} / \Gamma \mathrm{ra}\end{array}$ & \\
\hline $\begin{array}{l}1-3 \\
0,06\end{array}$ & $\begin{array}{c}10 Д 3 ; \\
\text { ЗДН-0,75 }\end{array}$ & 32,9 & $21,4^{ \pm 1,53}$ & 0,50 & $\frac{1,7^{ \pm 0,14}}{0,58-2,12}$ \\
\hline $\begin{array}{l}1-2^{*} \\
0,06\end{array}$ & $\begin{array}{c}\text { 10Дз; } \\
\text { ЗДН-0,35 }\end{array}$ & 24,1 & 3,9 & 1,10 & $\frac{1,2^{ \pm 0,17}}{0,23-2,41}$ \\
\hline $\begin{array}{l}3-1 \\
0,09\end{array}$ & $\begin{array}{l}\text { 8Акб2Лпд; } \\
\text { 3ДН - 0,98 }\end{array}$ & 1,3 & $1,9^{ \pm 0,04}$ & 0,02 & $0, \frac{1,1^{ \pm 0,03}}{0,72-1,23}$ \\
\hline $\begin{array}{l}3-3 \\
0,09 \\
\end{array}$ & $\begin{array}{c}\text { 7Акб2Лпд1Кл; } \\
\text { ЗДН-0,95 } \\
\end{array}$ & 13,2 & $23,4^{ \pm 0,59}$ & 0,36 & $0 \frac{0,9^{ \pm 0,06}}{0,74-1,42}$ \\
\hline $\begin{array}{c}, \\
0,06 \\
\end{array}$ & $\begin{array}{c}\text { 5Д } 35 Я_{3} ; \\
\text { 3ДН-0,86 }\end{array}$ & $9,5 * *$ & $25,3^{ \pm 0,49}$ & 0,34 & $\frac{1,8^{ \pm 0,71}}{0,41-2,93}$ \\
\hline
\end{tabular}

Примітка: $H$ - висота розміщення ран на стовбурах; $Q$ - частка пошкоджених дерев, \%. Площа ран на деревах: $\mathrm{Si}$, - середня; $S_{\text {lгa }}$ - сумарна на 1 га. Висота $(h$, м) розміщення ран на стовбуpax дерев: $M^{\ddagger m}$ - середня, min - мінімальна, $\max$ - максимальна. * - доступна для автомобілів ділянка узлісся біля яру с красивими видами на став, де дерева мають по 5-17 механічних ран. **- окрім ран механічного пошкодження, $33 \%$ дерев пошкоджено вогнем (нагар в зоні стовбурів $0-1,3$ м), 8 \% дерев зрубано.

3 віддаленням від кладовища (понад 60 м) та вул. Визволителів (150 м) навантаження відвідувачів знижується до середнього рівня, покращується стан дерев. Проте і тут деревостан сильно ослаблений (ПП1-С2; $I c=2,63)$. У надгрунтовому покриві поширені: Urtica dioica L., Chelidonium majus L., Galium odoratum (L.) Scop., Asarum europaeum L., Geum urbanum L., Impatiens parviflora DC., Stellaria holostea L., Carex pilosa Scop. Більш деградованими є доступніші для під'їду на автомобілях ділянки узлісся. Так, уздовж правої бровки найбільшого яру в місцях нерегульованого відпочинку населення трапляються витоптані, без ЖНП ділянки

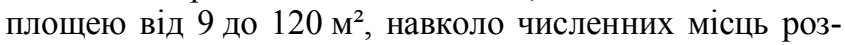


ведення багать площею $1,5^{ \pm 0,26} \mathrm{M}^{2}$ засміченість становить 4-15\%. Чверть дерев у таких зонах насадження мають кожне від 5 до 17 механічних ран площею $3,9^{ \pm 0,78} \mathrm{~cm}^{2}$ до 2,41 м висоти стовбура (див. табл. 2). На деградованих ділянках механічно пошкоджені кореневі лапи дерев. Отже, є певна загроза рекреаційного зниження грунтозахисної ролі цього деревостану, що може призвести до активізації описаного вище яру.

Далі від кладовища (600 м) у бік автотраси Київ Одеса на схилі $9^{\circ}-16^{\circ}$ до ставка Звірки шляхом терасування створене протиерозійне чисте дубове насадження 3 розміщенням дерев у культурі $4 \times 0,7$ м (ПП2). Тераси нарізані 3 перепадом висоти між ними 0,3 м (на схилі $\left.9^{\circ}\right)$ та 0,7 м $\left(16^{\circ}\right)$. Надгрунтовий покрив складається 3 Festuca valesiaca L., Achillea millefolium L., Poa nemoralis L., C. pilosa, S. holostea та ін., ЗПП травостою $-78 \%$, задерніння - $18 \%$. Завдяки відсутності поблизу привабливих для відпочинку місць насадження має незначне рекреаційне навантаження, його пересікають лише дві стежки, інших ознак дигресії немає. Проте деревостан сильно ослаблений $(I c=2,64)$, однак ще здатний захищати схил від водної ерозії.

Іншим місцем рекреаційного впливу на зелені насадження є рекультивований кар'єр "Карпівка" з видобутку граніту (площа 4,1 га; глибина 40-80 м), що розташований на північно-західній околиці передмістя Мішанка. Граніт перестали добувати на початку 1990-х років. Наразі кар'єр заповнений водою та використовується місцевими мешканцями для відпочинку. Їх приваблює також безіменний ставок, створений на р. Олександрівки, притоки р. Уманки. На схилі до ставка крутизною 8$22^{\circ}$ створено грунто- та водозахисний лісовий масив (4,2 га), що зростає в умовах свіжої акацієво-липової діброви. Схема розміщення дерев у культурі $2,5 \times 0,7$ м, розміщення рядів $-\mathrm{A} \kappa_{\sigma}-Л_{\Pi_{д}}-\mathrm{A} \kappa_{\sigma}-\mathrm{K}_{\Gamma}-Л \Pi_{д}-\mathrm{A} \kappa_{\bar{\sigma}}-\mathrm{A} \kappa_{\bar{\sigma}} . \mathrm{У}$ травостої поширені: S. holostea, G. odoratum, A. europaeum, C. pilosa. Щодо ступеня дигресії варто порівняти стан двох ідентичних за лісівничо-таксаційними показниками насаджень, що зазнають: 1) помірного рекреаційного навантаження - деревостан із зімкнутим $(0,96)$ наметом, без галявин, породним складом 8Акб2Лпд (ПП3-С1), що зростає на схилі $22^{\circ}$, на відстані 120 м від кар'єру, 80 м від ставка, 300 м від автомобільної дороги напряму "вул. Максима Залізняка - с. Городецьке" та 2) інтенсивного навантаження - на схилі $8^{\circ}$, породним складом 7Акб2Лпд1Клг (ПП3-С3) - 400 м до кар'єру, 50 м до ставка, 150 м до автомобільної дороги (див. табл. 1).

Встановлено, що в зоні помірного впливу негативні наслідки незначні. На ділянці покриття ЖНП становить $55 \%$, витоптаність його - $1,8 \%$, є лише одна стежка завширшки 0,4 м 3 порушеною підстилкою. Слідів розведення багать немає, механічно пошкоджених дерев мало (1,3\%), вони мають лише по 1-2 незначні рани (див. табл. 2). Індекс стану $T$. cordata становить 2,61, R. pseudoacacia - 2,63. Більш деградованою є частина лісового масиву (ПП3-С3), що розташована ближче до автошляху і має привабливіші для відпочинку населення умови: задернілі галявини, більш зріджений (ЗДН $=0,84)$ без чагарників деревостан і пологіший схил. Це насадження розчленоване мережею стежок завширшки 0,3-1,5 м, на 37 \% площі порушений ЖНП, $4 \%$ території витоптано до мінерального шару грунту, $13,2 \%$ дерев мають значні рани від сокири (див. табл. 2). Порівняно з ділянкою помірного впливу, тут гірший стан має $T$. cordata $(3,36)$ та $R$. pseudoacacia $(3,28)$. Внаслідок зрідження деревостану дерева цих видів мають меншу середню висоту та більший діаметр (див. табл. 1). Найбільша деградація насадження біля ставка. Так, рекреаційно приваблива ділянка площею 110 м $^{2}$ має таку структуру за ознаками деградації: $5 \%$ засмічено побутовим сміттям; $12 \%$ - кострища; $37 \%$ порушений ЖНП; 13 \% території витоптано до мінерального шару грунту; решта (33\%) території не пошкоджена.

Порівняно з лісовими масивами, значно вразливіші щодо антропогенного впливу лінійні, доступні для людини берегозахисні лісосмуги. Наприклад, дубово-ясеневе чотирьохрядне насадження (ПП4), що зростає по інший бік згаданого ставка (65 м - до автомобільної дороги, 480 м - до кар'єру, 30 м - до ставка). Схема розміщення дерев у культурі $2,5 \times 0,7$ м, розміщення рядів $Д_{3}-Я_{3}-Д_{3}-Я_{3}$. Між другим та третім рядами автотранспортом накатано грунтову дорогу шириною 3,5 м. На віддалі 15-20 від ставка засміченість берега становить $13 \%$, в зоні $25-40$ м - $2 \%$. Загалом 42,5 \% дерев пошкоджено: $33 \%$ - вогнем (нагар в зоні стовбурів 0-1,3 м), 9,5\% - мають механічні рани від сокири і ножа. Зрубано $8 \%$ дерев. Порівняно з $F$. excelsior $(I c=2,62)$, сильніше ослаблений $Q$. robur $(I c=3,31)$. Деревостан втрачає грунтозахисну роль. На схилі крутизною $18^{\circ}$ довжиною 45 м, де витоптано травостій, виникло п'ять розмивів грунту завглибшки до $12 \mathrm{~cm}$, завширшки від 13$47 \mathrm{~cm}$, що призвело до часткового вимивання коріння дерев. Такі ерозійні розмиви сприяють концентруванню стоку, який надходить 3 автомобільної дороги під час інтенсивних дощів та сніготанення, що збільшує активність руйнування берегу та винесення продуктів ерозії в ставок.

Висновки. Отже, ступінь рекреаційного навантаження на захисні, рекреаційно-оздоровчі та природоохоронні насадження зеленої зони у межах міста Умані залежить від їхньої привабливості та віддаленості від комунікативної мережі міста, місць значної концентрації людей. Попри доволі розвинену й обладнану інфраструктуру та організоване регулювання відвідувань дендропарк "Софіївка" все ж таки зазнає механічного і пірологічного пошкодження дерев, інвазії рудерантів, витоптування травостою і грунтового покриву, що на крутих схилах призводить до площинної і вертикальної ерозії грунту, забруднення гідрологічної мережі продуктами ерозії. Особливої уваги потребують грунтозахисні та водоохоронні насадження щодо збереження їхньої екологічної ролі, оскільки на побережжях біля річок і ставків 3 привабливими умовами, краєвидами внаслідок нерегульованого відпочинку вони зазнають середньої і сильної рекреаційної дигресії. Так, прибережний схил до ставка Звірки має ступінь розчленування ярами 26,9 м/га, найбільший з яких сягає довжини 188 м, площі 0,58 га, глибини понад 8 м та має 14 глибоких відвершків. Хоча наразі яри заросли травостоєм, проте зниження захисних функцій згаданих насаджень може активізувати ерозійні процеси на схилах до річок Уманки та Олександрівки. Зокрема, поблизу кладовища 3 могилою духовного наставника хасидів територія масивних лісових культур дуба звичайного і їхніх узлісь інтенсивно засмічена і витоптана, до третини дерев мають механічні рани, понад $14 \%$ пошкоджені низовою 
пожежею. Біля кладовища (0-30 м) їхній ріст та розвиток загальмовані, деревостан починає всихати. На найбільш деградованих ділянках узлісь 3 мальовничими краєвидами і пікніковими галявинами кожне четверте дерево має від 5 до 17 механічних ран. Значно менше рекреаційне навантаження на околицях Умані, таких як передмістя Мішанка. Проте й там біля водойм, навколо пікнікових майданчиків захисні насадження деградують. Доступні лісосмуги уздовж берега вирубуються населенням, дерева інтенсивно пошкоджуються, травостій витоптується, що призвело вже до активізації розмивів грунту та часткового вимивання коріння дерев. Тому зелена зона у межах міста потребує удосконалення організації зон відпочинку і регулювання їх відвідування 3 урахуванням ландшафтно-екологічних, урбоекологічних та природоохоронних норм. У захисних насадженнях необхідно насамперед враховувати їх цільове призначення, рекреаційну місткість, потенційну екологічну стійкість та сучасний санітарний стан, щоб не знижувати їх відповідних пріоритетних функцій.

\section{Перелік використаних джерел}

Anuchin, P. P. (1982). Forest taxation. Moscow: Lesn. prom-st, 547 p. [In Russian].

Herbut, O. V. (2008). Biological features of ornamental tree species used in landscaping of the of Uman city. Scientific Bulletin of $U N$ $F U, 18(1), 7-27$. [In Ukrainian].

Hrabovyi, V. M. (2013). Use of coniferous plants in green areas of Uman. The role of botanical gardens and arboretums in the conservation and enrichment of the biological diversity of urban areas: Materials of the International scientific conference, May 28-31, 2013. (pp. 63-65). Kyiv. [In Ukrainian].

Kucheriavyi, V. P. (1999). Urban ecology. Lviv: Svit, 360 p. [In Ukrainian].

Laptiev, O. O. (1998). Ecological optimization of biogeocenotic cover in modern urban landscape. Kiev: UEAN, 208 p. [In Ukrainian].

Lavrov, V. V., Blinkova, O. I., Ivanenko, O. M., \& Polishchuk, Z. V. (2017). Changes in consortial links of aphyllophoroid fungi and $Q u$ ercus robur $\mathrm{L}$. in the recreational forests of the green zone of Uman city. Ekolohiia ta noosferolohiia, 3-4(28), 5-20. [In Ukrainian].
Lavrov, V. V., Zhytovoz, A. V., \& Hrabovska, T. O. (2015). Anthropogenic threats to the arboretum "Sofiyivka". Pytannia bioindykatsii ta ekolohii, 20(2), 3-17. [In Ukrainian].

Maltseva, S. Y., Maltsev, Y. I., Solonenko, A. M., \& Bren, O. G. (2017). Anthropogenic transformation of the flora of urbanoecosystems of the Northern Pryazov territories. Biosyst. Divers., 25(3), 222-227. https://doi.org/10.15421/011734

Marno-Kutsa, O. Yu. (2014). Complex evaluation of tree plantations in the Uman city. Scientific Bulletin of UNFU, 24(9), 75-80. [In Ukrainian].

Poliakov, A. F., \& Pluhatar, Yu. V. (2009). Forest formations of Crimea and their ecological role. Kharkov: Novoe slovo, 405 p. [In Russian].

Pylypenko, O. I., Yukhnovskyi, V. Yu., \& Vedmid, M. M. (2004). Soil protection systems against erosion. Kiev: Zlatoiar, 435 p. [In Ukrainian].

Rat, M. M., Gavrilović, M. T., Radak, B. Đ., Bojana, Bokić, S., et al. (2017). Urban flora in the Southeast Europe and its correlation with urbanization. Urban Ecosyst., 20(4), 811-822. https://doi.org/10.1007/s11252-017-0645-6

Ricotta, C., La Sorte, F. A., McKinney, M. L., Pyšek, P., et al. (2009). Phytoecology of urban alien floras. Journal of Ecology, 97(6), 1243-1251. https://doi.org/10.1111/j.1365-2745.2009.01548.x

Sanitarni pravyla u lisakh Ukrainy. (1995). Sanitary rules in the forests of Ukraine. 1995. Resolution of the Cabinet of Ministers of Ukraine of 27 July. Kiev, 20 p. [In Ukrainian].

Shlapak, V. P., Kozak, N. I., Tereshchenko, Yu. F., et al. (2013). Determination of the damage degree of woody plants by misty white (Viscum album L.) in Uman "Pionersky" Park. Scientific Bulletin of UNFU, 23(6), 324-327. [In Ukrainian].

Simmons, B. L., Hallett, R. A., Sonti, N. F., Auyeung, D. S. N., \& Lu, J. W. T. (2016). Long-term outcomes of forest restoration in an urban park. Restoration Ecology, 24(1), 109118. https://doi.org/10.1111/rec.12281

Vorobev, D. V. (1967). Methods of forest typology research]. Kiev: Urozhaj, 388 p. [In Russian].

Voron, V. P., Bondaruk, M. A., Lavrov, V. V., et al. (2011). Monitoring and enhancing the resistance of anthropogenically disturbed forests: a compilation of URIFFM recommendations. Kharkiv: Nove slovo, $304 \mathrm{p}$. [In Ukrainian].

Williams, N. S. G., Hahs, A. K., \& Vesk, P. A. (2015). Urbanisation, plant traits and the composition of urbanfloras. Perspectives in Plant Ecology, Evolution and Systematics, 17(1), 78-86. https://doi.org/10.1016/j.ppees.2014.10.002

V. V. Lavrov, O. I. Slobodeniuk, L. A. Savchuk

Bila Tserkva National Agrarian University, Bila Tserkva, Ukraine

THE STATE OF GREEN PLANTATIONS IN UMAN

The problems of improving the structure and mode of green zones use in cities are considered. Insufficient coordination of the urban planning principles, urban ecology and nature protection causes these problems. The methods of forestry, urban ecology, landscape ecology and erosion, principles of comparative and gradient analyzes have been applied. The influence of human activity on recreational and health, protective and nature conservation stands is investigated using the example of an inner green zone in Uman (Ukraine). This article establishes the extend, the diagnostic and spatial peculiarities of their disturbance depending on their functional purpose, forestry and taxation characteristics, location in the landscape, relative to the objects of communication and to attractive centres of flock and people rest. It has been found that Sofiyivka Arboretum had undergone mechanical and fire damage trees, weed invasion, trampling vegetation and soil cover in the areas of the most attractive sites. This leads to surface and vertical soil erosion on the steep slopes. However, the most degraded soil and water protection plantations are in attractive places of the city river coastal protective strip. Near the cemetery with the Hasid spiritual master tomb, Quercus robur plantation is intensely clogged and trampled. One third of the trees have mechanical damages, more than $14 \%$ are damaged by fire. The stands in the edge lane above the River Umanka flood bed begin to degrade. It can activate the ravine system developed in the past. The ravines are grown over with grass stand. The dissection degree with ravines of the territory is $26.9 \mathrm{~m} / \mathrm{ha}$. The largest ravine reaches a length of $188 \mathrm{~m}$, an area of $0.58 \mathrm{~h}$, a depth of more than $8 \mathrm{~m}$ and has 14 deep partings. The protective plantation located in the suburbs is less degraded. The plantations near reservoirs, around picnic areas are medium and intensively damaged. They are being cut down somewhere. This led to the activation of soil erosion. Therefore, it is necessary to improve the organization of recreation areas and to regulate their visiting in Uman, taking into account landscape and ecological, urban, and environmental standards. Preserving priority functions of protective green plantations is necessary.

Keywords: protective plantations; recreational and healthful plantations; nature conservation plantations; recreational digression; soil erosion; improvement of organization and regulation of recreation areas. 